\title{
High Grade Paranasal Sinus Sarcoma
}

National Cancer Institute

\section{Source}

National Cancer Institute. High Grade Paranasal Sinus Sarcoma. NCI Thesaurus. Code C6850.

An aggressive malignant soft tissue neoplasm that arises from the paranasal sinus. It is characterized by the presence of high-grade histologic features. 